\title{
Kompetencje społeczne a ryzyko w sporcie
}

\section{Social competences and risk in sport}

\section{Streszczenie:}

W pracy zaprezentowano wpływ wybranych zmiennych, jak wiek, długość stażu, efektywność oraz poziom kompetencji społecznych na ilość decyzji ryzykownych w piłce ręcznej. Trzyletnie badania wskazały wpływ poziomu kompetencji społecznych na wynik sportowy.

Słowa kluczowe: sport, kompetencje społeczne, decyzje, ryzyko

\begin{abstract}
:
In the article was presented an influence of chosen variables: age, internship, effectiveness, level of social competence and amount of risky decisions in handball. Three-year-old examinations showed the income level of social competence influence on the sports result.
\end{abstract}

Keywords: sport, social competence, decisions, risk

\section{Wstęp}

W dzisiejszym sporcie coraz częściej różnica między wygranym a pokonanym jest minimalna. Czasem wynosi ona setne, czy tysięczne części sekundy, czasem centymetry, czy jedną bramkę. Podczas ostatnich Igrzysk zimowych w Soczi w 2014 roku polski panczenista Zbig- 
Marcin Kochanowski - Kompetencje społeczne...

niew Bródka w wyścigu decydującym o mistrzostwie olimpijskim wyprzedził rywala z Holandii o 0,003 sekundy. Mistrz olimpijski w pchnięciu kulą z Londynu Tomasz Majewski pokonał drugiego w konkursie finałowym Niemca różnicą zaledwie trzech centymetrów, przy czym obaj pchnęli kulę na odległość blisko 22 metrów. Wiele spotkań na tegorocznych Mistrzostwach Europy, zarówno tych rozgrywanych w Polsce w piłkę ręczną, jak i tych we Francji w piłkę nożną, kończyło się różnicą jednej bramki. Często wręcz o awansie do kolejnej rundy rozgrywek decydowała seria rzutów karnych. Coraz częściej zatem o wyniku sportowej rywalizacji może decydować jedno zagranie, jeden błąd, czy też jedna decyzja. Autor przeprowadził zatem badania, których celem było odnalezienie aspektów, które wpływają na ilość decyzji ryzykownych $\mathrm{w}$ sporcie. W niniejszym opracowaniu przedstawione zostaną jedynie wybrane zmienne, które korelowały z decyzjami ryzykownymi, podejmowanymi przez piłkarki i piłkarzy ręcznych.

\section{Proces decyzyjny}

Sytuacja, w której człowiek podejmuje decyzje, jest najczęściej złożona, a do samego procesu decyzyjnego może prowadzić wiele dróg. Czynniki, które wpływają na podjęcie takiej, a nie innej decyzji, są związane z wieloma zmiennym. Pierwszą z nich mogą być posiadane już przez decydenta doświadczenia. Wyciągając wnioski z wcześniejszych zagrań, czy to na treningu, czy na meczu, zawodnik w kolejnych analogicznych zdarzeniach na boisku może optymalizować swoje reakcje i podejmowane działania. Znajdując się w sytuacji decyzyjnej, człowiek odnosi jej ocenę do poprzednich zachowań swoich lub innych osób, które obserwował. Dlatego też wnioskowanie lub dobre działania w walce sportowej młody człowiek może wytrenować podczas treningu, ale także zaobserwować u innych sportowców w podobnych sytuacjach. Wówczas będzie mógł ocenić, czy określone działania, także ryzykowne, przynoszą ostatecznie korzyść. Im większą 
wiedzę posiada człowiek, tym trafniejsze stają się jego decyzje. Opierają się one wówczas nie tylko na działaniach intuicyjnych, ale przede wszystkim na procesie uczenia się przeprowadzonym w powtarzanych wielokrotnie ćwiczeniach podczas treningu sportowego. Jeden z byłych reprezentantów Polski w koszykówce, Adam Wójcik, pisał o tym, że nie musi obserwować swojej ręki podczas rzutu - odczuwając, jak ułożył rękę, często wiedział, jaki będzie efekt jego rzutu1. Kolejnym elementem, który ma istotny wpływ na proces decyzyjny, jest informacja. Brak aktualnej, czy pełnej informacji, może znacząco obniżyć skuteczność podejmowanych decyzji. Jeśli makler giełdowy ma informacje wpływające na ceny akcji, którymi jakimi obraca, może zarobić ogromne pieniądze. Jeśli zwiad wojskowy rozpoznał słaby punkt przeciwnika i przekazał tę informację do sztabu dowodzenia, będzie ona miała wpływ na decyzję o miejscu przeprowadzenia natarcia. Bramkarz, który od trenera zajmującego rolę „banku informacji” otrzyma wskazówki, w który róg bramki najczęściej wykonuje rzut karny dany zawodnik, może podjąć bardziej świadomą decyzję, w którą stronę wykonać interwencję. Co prawda w sytuacji sportowej, biznesowej, czy życiowej, nie panują rozwiązania matematyczne, czy algorytmy działania, więc zawsze istnieje ryzyko, że informacje będzie niepełna. Laureat Nagrody Nobla w dziedzinie ekonomii Herbert Simon wyraził to słowami: „Nie jest możliwe, by w jakimkolwiek czasie mieć doskonałą i kompletną informację wspomagającą podjęcie decyzji" 2 . Wielu autorów zwraca jednak uwagę na fakt, że spadek efektywności decyzji może nie wynikać z braku informacji, ale również $\mathrm{z}$ ich nadmiaru. Pamięć operacyjna ma swoje ograniczenia, tak więc zbyt wiele danych może być destraktorem i utrudnieniem. Pojemność pamięci krótkotrwałej, zwana również liczbą Millera, wynosi

\footnotetext{
1 J. Antczak, Rzut bardzo osobisty, Kraków 2013.

2 T. Ferris, 4 godzinny tydzień pracy, Warszawa 2011, s. 123.
} 
Marcin Kochanowski - Kompetencje społeczne...

$7 \pm 2$ jednostki ${ }^{3}$. Ograniczenie to oznacza, że nawet jeśli trener $\mathrm{w}$ dobrych intencjach przekaże zawodnikowi w przerwie meczu zbyt liczne dane o ustawieniu rywali, czy ich najczęstszych błędach, to części z tych informacji zawodnik po prostu nie przetworzy, bo nie zapamięta. Sama wiedza, czy to ta wynikająca z wykorzystania danych w pamięci długotrwałej wynikających z doświadczenia, czy też ta z pamięci operacyjnej, która jest efektem bieżącej analizy sytuacyjnej, nie muszą oznaczać podjęcia działań. Wiele osób ma wiedzę na temat tego, jak lepiej się odżywiać, dlaczego warto się ruszać czy prowadzić zdrowszy tryb życia. Mają wiedzę na ten temat, ale nie wprowadzają zmian, bo brak im motywacji. Aby rozpocząć działanie, człowiek powinien być do tego zmotywowany. Najczęstszym podziałem na rodzaje motywacji jest ten, który różnicuje kierunek jej powstawania4. Motywacja wewnętrzna wynika $\mathrm{z}$ pragnienia zaspokojenia potrzeb człowieka, zewnętrzna zaś to czynniki, które oddziaływają na człowieka z zewnątrz. W sporcie od dawna toczy się dyskusja, który rodzaj motywacji jest skuteczniejszy. Nie ma jednoznacznych wyników badań, które z całą stanowczością wskazywałyby jeden najefektywniejszy rodzaj motywacji. Może to wynikać ze zbyt wielu zmiennych, które wpływają nie tylko na motywy, ale również na efektywność działań w sporcie. Jarvis wyraża jednak opinię wskazującą na dominujące znaczenie jednej z opisywanych motywacji: „Współczesne badania wykazują, że motywacja wewnętrzna jest dla większości zawodników czynnikiem najważniejszym"5. Człowiek zmotywowany będzie podejmował próby i działania, niektóre z nich przyniosą korzyści, inne straty. Jednak sportowiec, które wcale nie będzie działał, nie odniesie zysku ani nie będzie mógł świętować zwycięstwa. Motywacja jest więc jednym z kluczowych elementów w procesie decyzyjnym. Kolejnym elemen-

${ }^{3}$ R. Makarowski, Czynnik ludzki w katastrofach i wypadkach lotniczych $w$ lotnictwie cywilnym w Polsce w latach 1990-1999. [w:] K. Popiołek (red.), Człowiek w sytuacji zagrożenia. Kryzysy, katastrofy, kataklizmy. Poznań 2001, s. 322.

${ }_{4}$ P. Zimbardo, R. Johnson, V. McCann, Psychologia kluczowe koncepcje, Warszawa 2011.

5 M. Jarvis, Psychologia sportu, Gdańsk 2003, s. 99. 
tem, który nie pozostaje bez znaczenia $\mathrm{w}$ trakcie procesu podejmowania decyzji, są emocje. Człowiek jako istota emocjonalna podejmuje decyzje, nie opierając się jedynie na analizach czy logicznym wnioskowaniu. Liczne badania, między innymi Tyszki, pokazują, że pobudzenie emocjonalne wpływa na jakość procesu decyzyjnego. I nie jest istotne, jaki to będzie rodzaj emocji, a samo to, że one się pojawią. Jak stwierdza Tyszka: „Najbardziej pożądany przy podejmowaniu ważnych decyzji byłby stan neutralny"6. Optymalną będzie więc sytuacja, gdy człowiek będzie podejmował decyzje bez udziału emocji. Niestety, zwłaszcza w sporcie taka sytuacja bardzo rzadko będzie miała miejsce.

Podsumowując rozważania dotyczące procesu decyzyjnego oraz czynników wpływających na jego jakość, można odnieść się do sytuacji, jaka miała miejsce w ostatnich 15 sekundach meczu pomiędzy Polską i Norwegią, decydującego w awansie do półfinału Mistrzostw Świata w piłce ręcznej w 2009 roku. Na tablicy był wówczas wynik remisowy, który dawał awans drużynie norweskiej. Norweski zawodnik popełnił błąd w ataku, a zgubioną przez niego piłkę przechwycił Artur Siódmiak. Wykorzystując swoje wieloletnie doświadczenie, a także informację podaną przez trenera kilkadziesiąt sekund wcześniej, zawodnik ten zdecydował się na rzut przez całe boisko do pustej norweskiej bramki. Wykazał się on w tym momencie dużą determinacją, a także odpornością na presję czasu (ostatnie sekundy meczu) i wyniku (rzut ten zadecydował o awansie Polski do strefy medalowej i ostatecznie przyczynił się do zdobycia przez polską drużynę brązowego medalu). Opisana tu sytuacja może być idealnym przykładem sytuacji ryzykownej w sporcie. Składała się na nią presja czasu, wyniku, umiejętność podjęcia się odpowiedzialności oraz zdecydowania się na działanie, które może przynieść zysk, ale jednocześnie jest obarczone ryzykiem poniesienia straty.

${ }^{6}$ T. Tyszka, Psychologiczne pułapki oceniania i podejmowania decyzji, Gdańsk 1999, s. 45. 
Marcin Kochanowski - Kompetencje społeczne...

\section{Ryzyko}

Ryzyko towarzyszy człowiekowi od początków jego egzystencji. W dzisiejszych czasach powstaje coraz więcej opracowań dotyczących tego zagadnienia, bo i też działania czy decyzje ryzykowne sięgają do coraz liczniejszych obszarów funkcjonowania człowieka. Możemy wyróżnić ryzyko zdrowotne, także zarówno w ujęciu pojedynczej osoby, czego przykładem może być notoryczne unikanie wizyt kontrolnych u lekarza czy też niewłaściwy sposób odżywiania się. 0 ryzyku zdrowotnym możemy też mówić w ujęciu chorób cywilizacyjnych, które dotykają całe społeczności. Ryzyko może również odnosić się do wypadków, zarówno tych komunikacyjnych, które mogą dotknąć niemal każdego z nas, jak i wypadków w pracy. Choć we wcześniejszych latach liczba wypadków przy pracy rosła, bo w roku 2007 było to 99 tysięcy takich zdarzeń, a w 2008 ponad 104 tysiące, to obecnie liczba ta znacząco spadła7. W 2014 roku Główny Urząd Statystyczny odnotował ponad 88 tysięcy poszkodowanych w wypadkach przy pracy, a w ubiegłym roku liczba ta przekroczyła jedynie 87,5 tysiąca ${ }^{8}$. Goszczyńska, badając ryzyko zawodowe, przestawiła wyniki badań, które wskazują, że wśród wielu zawodów występuje „efekt ego”. Oznacza on przecenianie poziomu ryzykowności wykonywanego zawodu wobec poziomu ryzykowności w innych grupach pracowniczych 9 . Ryzyko można również rozpatrywać w ujęciu ekonomicznym, w czym specjalizują się analitycy bankowi - ich wyliczenia mają bowiem jak najtrafniej oszacować, jakie inwestycje mimo stopnia swej niepewności mogą okazać się rentowne.

Mimo licznych opracowań różnych zagadnień i obszarów występowania ryzyka autorzy piszący na ten na jego temat bardzo często na-

\footnotetext{
$7 \mathrm{http} / / /$ www.stat.gov.pl/cps/rde/xbcr/gus/PUBL_pw_wypadki_przy_pracy_2008r.pdf

$8 \mathrm{http}: / /$ stat.gov.pl/obszary-tematyczne/rynek-pracy/warunki-pracy-wypadki-pr zy-pracy/wypadki-przy-pracy-w-2015-roku,3,22.html

9 M. Goszczyńska, Człowiek wobec zagrożeń. Uwarunkowania oceny i akceptacji ryzyka, Warszawa, 1997, s.196.
} 
potykają trudności już na etapie definicji tego zagadnienia ${ }^{10}$. Analizując literaturę, można zwrócić uwagę na dwa ujęcia podziału ryzyka: analityczne, które ryzyko sprowadza do wyliczeń matematycznych i logiczne, które opiera się na działaniach człowieka wynikających z wnioskowania na podstawie wcześniejszych doświadczeńn ${ }^{11}$. Odwołując się do Słownika języka polskiego PWN w wersji internetowej, możemy określić, że ryzyko to: „Możliwość, że coś się nie uda; też: przedsięwzięcie, którego wynik jest niepewny"12. Jednak w dalszej części swych rozważań autor ten zwraca uwagę, że działania, których wynik jest niepewny, mogą nie tylko prowadzić do straty, ale również przynosić korzyści. I w takim właśnie ujęciu ryzyko możemy rozpatrywać $\mathrm{w}$ środowisku sytuacji sportowej. $\mathrm{Z}$ jednej strony atak na bramkę przeciwnika może zakończyć się stratą piłki i kontrą, która daje duże szanse rywalom na zdobycie bramki, a więc stratę. Z drugiej zaś, bez podjęcia choćby próby zdobycia gola nie można wygrać spotkania. W związku z faktem wieloaspektowości sytuacji sportowej trudno będzie czasem wskazać, co jest zyskiem, a co stratą. Pojawić się tutaj może również rozróżnienie na zysk zespołu lub indywidualną stratę zawodnika. Obrońca goniący rywala w piłce nożnej, jeśli zdecyduje się na zagranie faulem, może zostać ukarany karą indywidualną, ale jednocześnie zagraniem tym ratuje swój zespół przed niebezpieczeństwem straty bramki, czy wręcz przegrania meczu. Przykładem doskonale ilustrującym taką sytuację może być zagranie urugwajskiego zawodnika w ostatnich momentach dogrywki ćwierćfinałowego meczu z Ghaną podczas Mistrzostw Świata w Republice Południowej Afryki w 2010 roku. W zamieszaniu pod własną bramką Suarez zatrzymał piłkę lecą w światło bramki, zagrywając ręką. Za takie zachowanie zawodnik został ukarany czerwoną kartką (a więc natychmiast musiał opuścić boisko, ale również nie mógł wystąpić w następnym meczu), a drużyna Ghany wykonywała rzut karny. Co ciekawe, zawod-

\footnotetext{
10 M. Goszczyńska, Człowiek wobec ..., op. cit., s. 31.

11 R. Makarowski, Granice ryzyka. Paradygmat psychologiczny, Kraków 2008, s. 9.

12 Ibidem, s. 13.
} 
Marcin Kochanowski - Kompetencje społeczne...

nik z Ghany nie wykorzystał tego rzutu karnego i kilkanaście minut później po serii rzutów karnych to zawodnicy Urugwaju cieszyli się $\mathrm{z}$ awansu do półfinału. Tak więc pozornie niekorzystne zagranie Suareza osłabiło zespół, ale jednocześnie pozwoliło mu uratować się przed porażką i ostatecznie grać dalej w mistrzostwach świata.

\section{Badania ryzyka wśród sportowców}

Badania zostały przeprowadzone w okresie od stycznia 2010 do marca 2012 roku, a liczba zbadanych wynosiła ponad 660. Grupę tę stanowili uczestnicy trzech kolejnych edycji ogólnopolskiego turnieju piłki ręcznej Poddębice Cup w latach 2010, 2011, 2012. W turnieju udział brali jedynie chłopcy, a ich rozpiętość wiekowa wynosiła od 12 . do 16. lat w pierwszym roku badania oraz 15-18 podczas ostatniego etapu badań w 2012 roku. Inną grupę zbadanych osób stanowili młodzieżowi reprezentanci Polski, grupa dziewcząt i chłopców w wieku 19-20 lat. Grupa reprezentantek i reprezentantów stanowiła niewielki procentowy udział wśród wszystkich badanych (zaledwie 5\%), ponieważ trener powołuje jedynie kilkunastoosobowy skład kadry narodowej. Kobiety wśród zbadanych stanowiły niecałe 3\%, dlatego też uzyskanych wyników nie można przenosić na szerszą populację. Innym ograniczeniem szerokiego upowszechnienia wyników jest fakt, że grupę badaną stanowili przedstawiciele jednej tylko dyscypliny sportu - piłki ręcznej. 0 ile więc można wnioski implikować do innych sportów zespołowych, o tyle ich przeniesienie na sporty indywidualne mogłoby już być nadużyciem. Badania zostały przeprowadzone przy wykorzystaniu kilku metod. Pierwszą stanowiły testy psychologiczne: Kwestionariusz Kompetencji Społecznych w opracowaniu Anny Matczak $^{13}$, Kwestionariusz NEO-FFI autorstwa Paula Costy i Roberta McCrea w opracowaniu Zawadzkiego, Strelaua, Szczepaniaka i Śliwiń-

13 A. Matczak, Kwestionariusz Kompetencji Społecznych, Warszawa 2011. 
skiej14. Narzędziem badającym poziom ryzyka był stworzony przez autora Kwestionariusz do Badania Decyzji Ryzykownych. Składa się on z czterech skal: 1) Skala Ryzyka Zdrowotnego, która obejmuje sytuacje ryzykowne mogące mieć konsekwencje zdrowotne dla badanego; 2) Skala Ryzyka Zespołowego, w której przedstawione są sytuacje związane z zachowaniami prospołecznymi przynoszącymi korzyść dla zespołu, czasem nawet kosztem kary indywidualnej dla zawodnika; 3) Skala Ryzyka Wynikowego - obejmująca decyzje, przy podjęciu których zawodnik bierze na siebie odpowiedzialność za wynik meczu, jak na przykład rzut karny, czy rzut w końcowej części spotkania; 4) Skala Pozostałego Ryzyka, w której skład wchodzą zachowania niemieszczące się bezpośrednio w żadnej z poprzednich skal, czyli na przykład takie, które dotyczą taktyki, reakcji na słowa trenera czy też wpływu poziomu meczu na ilość decyzji ryzykownych.

Ostatnim narzędziem wykorzystanym do prowadzonych badań była analiza dokumentacji meczowej, która pozwoliła między innymi na odniesienie ilości decyzji ryzykownych do ilości zdobytych przez zawodników bramek czy też kar, którymi zostali ukarani.

\section{Wnioski i implikacyjny charakter badań}

Istotnym wnioskiem wynikającym z przeprowadzonych badań jest to, że kilka zmiennych nie wpływało na ilość podejmowanych decyzji ryzykownych. Okazało się, że takie zmienne, jak wiek czy długość posiadanego doświadczenia nie wpływały na ilość decyzji ryzykownych. Zawodnicy młodzi, jak i starsi; ci, którzy trenowali dopiero od kilku miesięcy i ci, których doświadczenie boiskowe wynosiło ponad 5 lat, podejmowali podobną ilość decyzji ryzykownych. Wyniki pokazały też, że nie występują różnice istotne statystycznie pomiędzy zawodnikami z dużą i niewielką ilością zdobywanych bramek, tak więc efek-

14 B. Zawadzki, J. Strelau, P. Szczepaniak, M. Śliwińska, Inwentarz osobowości NEOFFI Costy i McCrae, Warszawa 2010. 
Marcin Kochanowski - Kompetencje społeczne...

tywność mierzona liczbą zdobytych bramek nie jest wyznacznikiem ilości podejmowanego ryzyka.

Jedną ze zmiennych, które korelowały z ilością decyzji ryzykownych był poziom kompetencji społecznych. W trzech z czterech skal ryzyka poziom KKS był statystycznie istotnie różny: Skala Ryzyka Wynikowego (test Wilcoxona, $\mathrm{W}=208.00, \mathrm{p}<0.0146$ ), Ryzyko Zespołowe, którego rozkłady także są statystycznie istotnie różne (jednostronny test Wilcoxona, $\mathrm{W}=89.00, \mathrm{p}<0.0277$ ), a także skala Pozostałego Ryzyka (test Wilcoxona, $\mathrm{W}=233.00, \mathrm{p}<0.0008$ ).

Interpretując przedstawione powyżej wyniki, możemy stwierdzić, że zawodnik, który ma wyższe kompetencje społeczne, a więc czuje się pewniej wśród swoich kolegów, ale również pewniej podczas ekspozycji społecznej, jaką jest występ sportowy, będzie podejmował więcej działań, więcej aktywności, wreszcie więcej decyzji, w tym także decyzji ryzykownych. Nie obawiając się negatywnej oceny innych, sportowiec będzie bardziej zdecydowanie reagował w sytuacjach, które mogą przynieść korzyści. Co ważne, rozpatrując dokładnie uzyskane wyniki, można dostrzec, że zawodnicy o wyższym poziomie kompetencji społecznych nie boją się podjąć ryzyka zespołowego, a więc poświęcić celów własnych, jak to zrobił Suarez. Jednocześnie osoby te nie obawiają się podjąć także ryzyka wynikowego, czyli wziąć na własne barki odpowiedzialności za wynik - jak Artur Siódmiak w ostatnich sekundach meczu z Norwegią.

Podsumowując wyniki uzyskane $\mathrm{w}$ przeprowadzonych badaniach oraz odnosząc je do praktycznego zastosowania, można postulować, by uczulić trenerów na rozwój kompetencji społecznych wśród młodych zawodników. Korzyścią bezpośrednią dla trenera będzie rozwój zawodnika, który będzie gotowy poświęcić własne cele dla dobra zespołu, ale również będzie gotów na podjęcie odpowiedzialności za wynik spotkania. Korzyściami wykraczającymi poza ramy sportowe będzie rozwój człowieka, a nie tylko sportowca. Człowieka, który budując swoje kompetencje społeczne, staje się pewniejszy siebie, ale również nie boi się zaryzykować, aby osiągnąć sukces. 


\section{Bibliografia:}

Antczak J., Adam Wójcik Rzut bardzo osobisty, Wydawnictwo Sine Qua Non, Kraków 2013.

Ferris T., 4-godzinny tydzień pracy, Wydawnictwo MT Biznes, Warszawa 2011.

Goszczyńska M., Człowiek wobec zagrożeń. Uwarunkowania oceny i akceptacji ryzyka, Wydawnictwo „Żak”, Warszawa 1997.

Jarvis M., Psychologia sportu, Gdańskie Wydawnictwo Psychologiczne, Gdańsk 2003.

Kochanowski M., „Umiejętność podejmowania decyzji ryzykownych, a efektywność w sporcie", niepublikowana rozprawa doktorska, Uniwersytet Gdański, Gdańsk 2016.

Makarowski R., Czynnik ludzki w katastrofach i wypadkach lotniczych $w$ lotnictwie cywilnym $w$ Polsce $w$ latach 1990-1999, [w:] K. Popiołek (red.), Człowiek w sytuacji zagrożenia. Kryzysy, katastrofy, kataklizmy, Wydawnictwo Stowarzyszenie Psychologia i Architektura, Poznań 2001.

Makarowski R., Granice ryzyka paradygmat psychologiczny, Oficyna Wydawnicza „Impuls”, Kraków 2008.

Matczak A., Kwestionariusz Kompetencji Społecznych, Pracownia Testów Psychologicznych PTP, Warszawa 2011.

Tyszka T., Psychologiczne pułapki oceniania i podejmowania decyzji, Gdańskie Wydawnictwo Psychologiczne, Gdańsk 1999.

Zawadzki B., Strelau J., Szczepaniak P., Śliwińska M., Inwentarz osobowości NEOFFI Costy i McCrae, Pracownia Testów Psychologicznych PTP, Warszawa 1998.

Zimbardo P., Johnson R., McCann V., Psychologia kluczowe koncepcje, Wydawnictwo Naukowe PWN, Warszawa 2011.

\section{Netografia:}

http://stat.gov.pl/obszary-tematyczne/rynek-pracy/warunki-pracywypadki-przy-pracy/wypadki-przy-pracy-w-2015-roku,3,22.html (dostęp: 24.09.2016).

http://www.stat.gov.pl/cps/rde/xbcr/gus/PUBL_pw_wypadki_przy_pracy_2 008r.pdf (dostęp: 20.09.2016). 
Marcin Kochanowski - Kompetencje społeczne...

http://www.newsweek.pl/sport/kim-jest-zbigniew-brodka-zbigniewbrodka-sylwetka-biografia-soczi-2014-lyzwiarstwo-szybkie-newsweekpl,artykuly,280884,1.html (dostęp: 23.09.2016).

http://www.sport.pl/londyn2012/1,125850,12251360,Londyn_2012_Pchn iecie_kula_Tomasz_Majewski_obronil.html (dostęp: 23.09.2016). 